\title{
Cultural additivity and mindsponge as novel research paradigms for studying the manifestations of "social harmony" in Confucian societies
}

\author{
Ho Manh Tung \\ Ritsumeikan Asia Pacific University \\ Beppu, Oita, Japan
}

September 12, 2020

The concept of "social harmony" is the bedrock of Confucian socio-political thoughts. As Confucianism is born out of the Warring States in early Chinese history, the system of thoughts focuses heavily on maintaining harmony in society (Ryan, 2015; Vuong et al., 2020). Recently, the Chinese government has promoted this concept as one of their major political ideals (Andrej, 2019; Kirk, Lee, \& Micallef, 2020). Researchers in the East and the West have started to pay dividends to this concept and studying its manifestations in various fields: the press system (Winfield, Mizuno, \& Beaudoin, 2000), business ethics (Chung, Eichenseher, \& Taniguchi, 2008; Wang \& Juslin, 2009), etc.

The problem with the current literature is that there is not yet a method to quantify social harmony, despite the growing datafication trend around the world (McStay, 2018). This, I suspect, might be the reason for such sporadic research efforts spent on this subject area. Moreover, the underlying phenomenology of social harmony does not 
attract adequate attention from the research community; thus, it is starving of a clear conceptual framework.

As such, I propose the framework of "cultural additivity" as a possible framework for the quantitative study of social harmony. Cultural additivity is the phenomenon of the mixing of cultural values and norms into an existing system. Through the Bayesian statistical analysis, a study of the mixing of cultural values in folktales has shown how Confucianism strongly accommodates the values of Buddhism and Taoism (Vuong et al., 2018). More importantly, a subsequent quantitative study, within the framework of cultural additivity, also provides substantial evidence that Confucian values are antithetical to violence and conflicts (Vuong et al., 2020). For these reasons, I believe cultural additivity provides a good theoretical framework for future quantitative studies of Confucian social harmony.

A complete account of social harmony and cultural additivity must include a subjective point of view. Here, I propose the "mindsponge model" to be used to study the phenomenology of social harmony and cultural additivity. In the mindsponge model, the human mind is analogized to a sponge which has a center, containing its core values, and a periphery, subjecting to new values. Then there is a constant process of filtering, rejecting, and selecting values, narratives, and ideas that shape and reshape the core. This process has been extensively discussed in the context of acculturation in the entrepreneurial world by Vuong and Napier (2015) and Vuong (2016). Such discussion can be extended towards a phenomenological viewpoint of how Confucian social harmony is maintained or destroyed. 
Maintaining social harmony in the traditional view of Confucianism is about preserving the fundamental social hierarchies (i.e., ruler-ruled, father-child, husbandwife), making a face, and giving face for others. However, we are living in a globalized and digitalized era, whereby hyperconnectivity implies Confucian traditional values are incessantly encountering some of their antithetical Western counterparts. New research paradigms into how people in Confucian cultures make or break social harmony are necessary. I believe "cultural additivity" and "mindsponge" can fulfill this role.

\section{References}

Andrej, U. L. E. (2019). Harmony as an ethical and political idea. Asian Studies, 7(1), 115-128.

Chung, K. Y., Eichenseher, J. W., \& Taniguchi, T. (2008). Ethical perceptions of business students: Differences between East Asia and the USA and among “Confucian” Cultures. Journal of Business Ethics, 79(1), 121-132.

Kirk, H. R., Lee, K., \& Micallef, C. (2020). The Nuances of Confucianism in Technology Policy: an Inquiry into the Interaction Between Cultural and Political Systems in Chinese Digital Ethics. International Journal of Politics, Culture, and Society, 124.

Ryan, N. (2015). Civilizing humans with shame: How early Confucians altered inherited evolutionary norms through cultural programming to increase social harmony. Journal of Cognition and Culture, 15(3-4), 254-284. 
Vuong, Q. H. (2016). Global mindset as the integration of emerging socio-cultural values through mindsponge processes: A transition economy perspective. In: J. Kuada (ed.) Global Mindsets: Exploration and Perspectives (pp. 109-126). Routledge, UK.

Vuong, Q.-H., Bui, Q.-K., La, V.-P., et al. (2018). Cultural additivity: behavioural insights from the interaction of Confucianism, Buddhism and Taoism in folktales. Palgrave Communications, 4(1), 143.

Vuong, Q.-H., Ho, M.-T., Nguyen, H.-K. T., et al. (2020). On how religions could accidentally incite lies and violence: folktales as a cultural transmitter. Palgrave Communications, 6(1), 82.

Vuong, Q.H., Napier, N.K. (2015). Acculturation and global mindsponge: an emerging market perspective. International Journal of Intercultural Relations 49, 354-367.

Wang, L., \& Juslin, H. (2009). The impact of Chinese culture on corporate social responsibility: The harmony approach. Journal of Business Ethics, 88(3), 433-451.

Winfield, B. H., Mizuno, T., \& Beaudoin, C. E. (2000). Confucianism, collectivism, and constitutions: Press systems in China and Japan. Communication Law and Policy, 5(3), 323-347. 